Article

\title{
Regional Electricity Models for Community Energy in Germany: The Role of Governance Structures
}

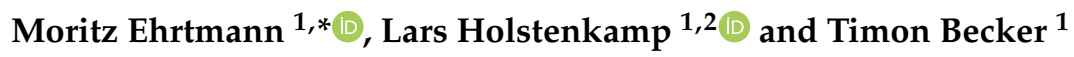 \\ 1 Institute of Banking, Finance and New Venture Management, Leuphana University Lüneburg, \\ Universitätsallee 1, 21335 Lüneburg, Germany; holstenkamp@uni.leuphana.de (L.H.); \\ tibecker@leuphana.de (T.B.) \\ 2 Institute of Sustainability Governance, Leuphana University Lüneburg, Universitätsallee 1, \\ 21335 Lüneburg, Germany \\ * Correspondence: ehrtmann@leuphana.de
}

Citation: Ehrtmann, M. Holstenkamp, L.; Becker, T. Regional Electricity Models for Community Energy in Germany: The Role of Governance Structures. Sustainability 2021, 13, 2241. https://doi.org/ $10.3390 /$ su13042241

Academic Editor: Marc A. Rose

Received: 19 December 2020

Accepted: 16 February 2021

Published: 19 February 2021

Publisher's Note: MDPI stays neutral with regard to jurisdictional claims in published maps and institutional affiliations.

Copyright: (c) 2021 by the authors. Licensee MDPI, Basel, Switzerland. This article is an open access article distributed under the terms and conditions of the Creative Commons Attribution (CC BY) license (https:// creativecommons.org/licenses/by/ $4.0 /)$.

\begin{abstract}
Community energy actors play an important role in the energy transition, fostering the diffusion of sustainable innovation in the renewable energy market. Because market conditions for business models in the renewable energy sector are changing and feed-in-tariff (FiT) schemes expiring, community energy companies are in the process of innovating their business models. In recent years, several community energy companies in Germany have entered the electricity retail market selling locally generated electricity from their renewable energy installations to customers in their region. We explore the evolving regional electricity business models for community energy companies in Germany, related governance structures, and the role they play for a sustainable energy transition. In order to implement these complex business models, community energy companies cooperate with professional marketing partners (intermediaries), which are capable of taking over the tasks and obligations of electricity suppliers. Through a series of expert interviews and desk research, we identify three distinctive regional electricity business models and examine opportunities and challenges to their implementation. Results show that there are different forms of cooperation, leading to specific governance structures and creating a set of new value propositions. Through these forms of cooperation, business networks emerge, which can function as incubators for sustainable innovation and learning for the post-FiT era.
\end{abstract}

Keywords: community energy; business model innovation; regional electricity retail; intermediary; governance; cooperation

\section{Introduction}

The energy transition requires socio-economic and technological innovation to foster decarbonization of the energy system [1]. Community energy actors have become an important element of energy markets in many European countries and a driving force of sustainable innovation processes, promoting the energy transition at a local level [2-4]. In the last twenty years, citizens have taken a lead and established community energy companies (CECs) to build and operate renewable energy (RE) installations. In the following, CEC denotes a firm that is majority owned by people from the region, in which the RE installation is located. Thus, they combine both dimensions highlighted by Walker and Devine-Wright-process (open, participatory) and outcome (local share in economic gains). Most CECs in Germany are legally structured as registered cooperatives, limited liability partnerships, or civil law associations [5]. In Germany, more than 1700 community energy companies had been founded by the end of 2016 [6]. Offering investment options in RE installations and opportunities for democratic governance of energy systems, CECs have made a significant contribution to a change towards a sustainable energy system $[4,7,8]$. The business activities of CECs were based on a relatively low-risk and replicable business model, which focused mainly on the operation of RE plants and the feed-in of the 
generated electricity into the grid [9]. For several years, the German Renewable Energy Sources Act (EEG) guaranteed a fixed feed-in tariff (FiT) or variable feed-in premium (FiP) on the electricity fed into the grid from RE plants and provided favorable conditions for the growth of CECs [10]. However, the conditions for operating new renewable energy installations have deteriorated in recent years [9]. In Germany, legal amendments to the EEG have led to a reduction in tariffs for rooftop PV systems. Since 2017, large renewable energy plants, such as wind farms, have to enter tenders in order to be eligible for a FiP. After 20 years of state support, many old community-owned plants will not be covered by the FiT schemes anymore. Not only in Germany, but also in several European countries, the framework conditions for low-risk community energy business models are getting worse, and FiT policies are gradually disappearing [11,12]. This is the main reason why, in Germany, the number of energy cooperatives has been (nearly) stagnating since around 2014. Similar observations apply for other types of CECs in Germany. If CECs want to continue to play an important role in the future energy market, they have to develop new business models $[9,12,13]$.

One promising business option for CECs is to enter the electricity retail market and to sell their own generated electricity to retail customers in the region [14]. Selling electricity to customers requires professional structures, as the legally regulated obligations and tasks of an energy supplier must be fulfilled [15]. In recent years, the CECs, which are usually managed on a voluntary basis, have therefore entered cooperation with energy suppliers in order to develop a regional electricity product $[11,16]$. These cooperative arrangements are a fairly new organizational innovation, leading to new forms of regional energy supply models [14].

Perhaps for this reason, little research has been conducted on these business models. In the German context, empirical studies have yet to examine community energy regional retail models in detail. Thus, the different options for CECs to regionally market their electricity have not been described and classified. There is also a lack of empirical studies that analyze the different collaborative arrangements, which have been established through developing theses business models. It is not clear which forms of cooperation exist, who the key actors are, and how the interdependent business activities in these models work. There are studies that show that energy intermediaries support business models of CEC as enablers and facilitators and thus foster business model innovation [11,16]. We assume, however, that the close interconnection in regional electricity models provides additional values for community energy actors as well as for the wider energy system [17] Studies, especially from the UK, have shown that local energy business models can support the expansion of RE installations, be drivers of technological and social innovation, and promote local value retention and energy democracy $[2,12,14]$. However, there has been little research on the different opportunities emerging from the diffusion of regional retail models and corresponding networks of different interdependent business actors potentially contributing to the energy transition.

These research gaps lead to three research questions addressed in this study:

- Which business models exist for community energy companies for retailing regional electricity? What are the main differences?

- Which roles do intermediaries play? What are the governance structures of the interdependent business models?

- How do regional electricity models contribute to the energy transition in Germany?

With this study, we extend the business model literature on community energy by analyzing regional electricity models in Germany and by developing a typology of regional electricity business models. In addition, we highlight the importance of the governance element in business model research in the energy sector. By doing so, we contribute to the understanding of the emergence of organizational innovations, such as new forms of business cooperation, and of their value in the energy sector. The paper is structured as follows: Section 2 gives an overview of the academic literature on the regional electricity models, community energy, cooperation, and business model innovation in the energy 
sector. Additionally, we propose an analytical framework, which we then use to analyze different regional business models. Section 3 describes the methods used to collect and analyze the data for this empirical study. In Section 4, we present the results. Section 5 discusses the role of governance structures and cooperation as well as the role of regional electricity models for the energy transition. The paper ends with summary of key findings and recommendations for further research in Section 6.

\section{Literature on Regional Electricity, Community Energy, and Business Models}

\subsection{Regional Electricity}

Distributed renewable energy installations allow generation and consumption to converge spatially and create new energy systems, where electricity is consumed close to its place of generation. The ongoing diffusion of renewable energy installations around the world requires a re-organization of the formerly centralized energy system [4]. This includes the development of various models that enable the distribution of locally generated electricity in a region [18]. The role of retailing regionally generated electricity has so far been an underrepresented topic in the scientific debate on energy transitions $[14,19,20]$. In the context of regional electricity systems, scientific studies on prosumers stand out. This relatively new type of actor is characterized by consuming the self-generated electricity close to its point of generation $[18,21]$. Through self-consumption, local energy trading, and developing entirely new business models, prosumers actively shape local energy systems and could be key players in a more participative and democratized energy system $[17,21]$. Recently, some studies have focused on the role of collective prosumers, where citizens act together to actively participate in the energy market [4,12,21-24]. As several studies indicate, collective prosumers can be key players to initiate technical and socio-economic innovations that contribute to a low-carbon energy transition by investing in renewable energy installations and developing new types of local energy systems [4,21,22]. Collective prosumers are characterized by a variety of organizational forms that interact with different actors (e.g., consumers, utilities, electricity trading companies, industrial enterprises, policy actors) in order to realize their goals [22,25]. How this interaction between the various actors is organized is, however, a relatively unexplored field.

There are studies which deal with the question of how collective prosumers can participate in models where renewable electricity is distributed locally $[4,12,14,23]$. So far, the main focus of researching prosumer innovations for marketing electricity has been on peer-to-peer (P2P) models in which prosumers trade electricity among themselves [26]. These P2P models are usually based on individual households, generating a surplus of electricity that they cannot store in their own battery system and then offer it for sale in the immediate proximity. However, due to legal restrictions and/or economic reasons, there have only been a few pilot projects in Europe so far [12]. Beneath P2P models, Brown et al. identify other local electricity models, where collective prosumers are actively involved and electricity is distributed close to its place of generation [12]. The UK "local energy company" model comes closest to a model where collective prosumers develop a regional electricity product to retail the locally generated electricity from their renewable energy installations to customers. Hall and Roelich examine innovative regional supply business models for the UK, but not focusing in community energy models explicitly [14]. There are few scientific studies that deal with regional electricity as a product sold to retail customers. Most studies on regional electricity products deal with the customer preferences of regional electricity $[19,27,28]$. These studies show that electricity tariffs, which highlight the regional origin of the electricity, can have a positive influence of the customer decision. Tabi et al. emphasize the potential of regional electricity products for certain target groups, if the origin of the electricity can be identified for customers [28]. Additionally, Herbes and Ramme assume that the regional origin is so far an undervalued attribute of electricity products and has the potential to attract customers [29]. The literature shows also that those electricity suppliers that operated mainly regionally were regarded positively by customers $[19,30,31]$. Results from the studies of customer preferences and 
prosumer models show that the retailing of regional electricity has the potential to become a functioning business model $[12,19]$.

For Germany, the possibilities for retailing regional electricity have so far been viewed primarily from a legal and economic perspective. Peters et al. show that the national energy regulatory framework plays an important role for the design of regional electricity models [20]. We briefly outline the regulatory framework that is important for the retailing of regional electricity in Germany below:

- In most cases, RE installations rely on a public support scheme, with a feed-in tariff paid to the owners of the plant [15].

- Electricity from RE plants larger than $100 \mathrm{~kW}$ is marketed via a market trader. In this case, a market premium (FiP) is paid to the owner of the RE plant [15].

- The sale of electricity to retail customers is associated with a number of legal obligations and tasks that require professional corporate structures [9].

- Since 2016, there has been a legal framework for the labeling of regional electricity. Regional certificates (guarantees of regional origin) have been introduced to prove the regional origin of an electricity tariff [15]. The registry has been in place since 2019.

- Although there are still legal uncertainties, there is agreement that regionally generated electricity may only be marketed as regional electricity if the origin can be verified [15].

These characteristics significantly affect the design of regional electricity products in Germany and are relevant for community energy companies that are setting up their own regional electricity product. However, how CECs deal with these legal requirements in practice to develop a regional electricity product is largely unexplored $[19,20]$.

\subsection{Business Model Concept}

The business model concept is a frequently applied tool both in academic research and in management practice. It is used for analysis, classification, and comparison of the way companies do business [32]. According to Teece [33], business models describe how companies use their resources and opportunities to create economic value. As Zott et al. state, the business model concept can be seen as a holistic approach that emphasizes a system level, which also takes into account external environmental factors that influence the business model [34].

The business model concept is considered an appropriate tool to evaluate the strategies of organizations and firms to address sustainability challenges [35]. In order to achieve the ambitious sustainability goals, new business models will be needed that emerge from business model innovations. Following Boons and Lüdeke-Freund's argumentation, new business models emerge from technical, organizational, or social innovations, which can lead to systemic sustainability innovations [36]. Several studies indicate that innovative business models can dissolve path dependencies and promote emerging sustainable energy systems $[12,14,17,35,37]$. These innovative business models try to create and deliver ecological, economic, and social value to the wider system [35]. How to deliver and capture the value, not only for customers, but also for the wider system, is a central element of sustainable business models. Bocken et al. define a set of generic sustainability value propositions [38]. The most important for our study are substituting fossil energy with renewables, encouraging sufficiency (e.g., demand management), and re-purposing business for society $[14,38]$. There is a large amount of scientific literature on the subject of business models and business model innovation in the energy sector, and several studies focus on the renewable energy sector in general $[9,12,14,37,39-44]$. The literature points out that innovative energy business models can provide business opportunities for various market participants in a changing market environment as well as provide solutions for more sustainable energy systems and overcome unsustainable industrial structures $[12,14,37,43]$. In addition to the system component, business model innovation can initiate a process of renewing organizations, renewing growth and profits [45]. As Chesbrough points out, organizational innovation is central to this [45]. Business model innovation can open up 
new value sources and generate new revenues for prosumers and community energy actors, which they will rely on in a changing energy market environment $[9,12]$.

When analyzing regional electricity models for energy communities, the system boundaries extend beyond the individual company $[46,47]$. Business models usually have a network-like structure, which includes various activities in which several companies are involved in order to deliver value to customers [48]. Different scholars suggest that value creation is often a co-created process, and inter-organizational relationships of firms are central to this $[46,49]$. This applies especially to electricity retailing, where complex organizational structures of different partnering firms are present. In order to offer and deliver products or services to their customer base, companies enter collaborative arrangements, without which they would not be able to develop complex business models [50]. Therefore, in this study, a system perspective is applied to analyze the business models of community energy companies and their business partners [46]. Hellström et al. show that the business model concept is an appropriate tool to analyze interdependent firms, which span together a networked architecture of value creation [46]. In the case of regional electricity models, community energy companies always enter a business relationship with a marketing partner, which acts in most cases as the electricity supplier [11]. Following the business model perspective, this study focus on a focal firm, namely a community energy company, but takes the business activities of the intermediary marketing partner into account, without which the business model would not be practicable. Therefore, a focus of this study is the analysis of the governance component, as regional electricity models with community energy enterprises involved are highly networked arrangements [12].

\subsection{Community Energy Companies}

In the context of regional electricity business models, we focus on community energy companies. There is a large and ever-growing body of literature on various aspects of community energy companies and initiatives (see, among others, [5,51-61]). They are reported to have played a pivotal role in developing renewable energies in several countries such as Denmark and Germany, especially in the pioneering phases [62,63]. In Germany, the number of community energy cooperatives alone had increased significantly since 2008 up until around 2013/14 [6,64]. Triggered by regulatory changes, community energy companies now face the challenge of innovating their business models from feed-in tariff (FiT)-based to more demanding and risky models, a development that is described for several countries such as Germany [9] and the UK [11,65] or subsectors such as community wind [66].

Community energy scholars have also applied the business model concept to community energy. However, they have more often implicitly than explicitly analyzed (parts of) community energy companies' business models (see e.g., [65]). Works on social enterprises and non-profit organizations' business models demonstrate the general applicability of the concept beyond the for-profit sector $[67,68]$. Community energy companies or initiatives have been characterized as hybrids between for-profit and non-profit organizations [69-71]: Not only profit-seeking, but also non-financial aims such as social and ecological gains motivate citizens to invest in renewable energy installations through these community companies $[8,72,73]$.

The present work contributes to the few studies that explicitly make use of the business model literature: Dilger et al. [50] develop a conceptual framework for analyzing community energy cooperatives' business models. Herbes et al. [9] give an overview of community energy cooperatives' business models in general and analyze barriers for business model innovation and strategies to overcome them, also in a German context. Nolden et al. [11] specifically focus on community solar initiatives in the UK in their longitudinal, in-depth study of this type of community energy. They highlight the institutional environment and organizational responses in the community solar sector to changes thereof. Compared with Herbes et al., we zoom in on one of the identified (future) business models, i.e., "local 
direct sales of electricity" [9]. In line with Herbes et al. [9], Nolden et al. [11], and Roby and Dibb [65], we emphasize the importance of cooperation.

\subsection{Cooperation Mechanism in Business Models}

Several authors have stressed the role of intermediaries in facilitating the foundation of community energy companies and the development of projects by these companies [2,11,16,74-77]. Herbes et al. [9] identify "partnering" or "cooperation" as one of the potential strategies besides professionalization and mergers that energy cooperatives can use for corporate growth, similar to advice given to municipal utilities [43]. They list other energy cooperatives, cooperative banks, housing cooperatives, established players in the energy industry, and municipal utilities as potential partners. The latter two categories are especially relevant in the context of regional electricity retail. Regarding municipal utility companies, they emphasize the ambivalent stance that these may take towards community energy companies, alternating between competitors and allies. For the UK context, Roby and Dibb [65], Nolden et al. [11], and Creamer et al. [78] have recently worked out the resultant hybrid governance structures or "entanglements" that have developed from such interactions between community groups, local councils, and other types of intermediaries and private sector actors in the UK's PV, wind, and local flexibility markets, respectively.

We highlight this aspect of business models in another context, namely regional electricity retailing in Germany, and compare our findings with results from the UK studies. Thus, the relationship between community groups and public authorities, which several authors scrutinize $[41,65,78-81]$, is of less importance here. Moreover, our subject of study differs from shared ownership structures in larger-scale PV or wind energy installations analyzed by Goedkoop and Devine-Wright [82]. Similar to findings by Goedkoop and Devine-Wright, however, we expected trust to play a significant role in developing cooperation and networks.

Partnerships or interorganizational relationships are a well-investigated field in economics and business studies [83-87]. Transaction cost theory sees them as a midway between market and hierarchy. Proponents of transaction cost economics (TCE) consider high asset specificity and uncertainty to be determinants for more hierarchy-like forms of cooperation such as joint ventures, whereas resource complementarity and small firm size are predictors of more market-like contractual forms such as long-term contracts [88]. Trust between the partners may function as substitute or complement for control [89]. In contrast, the resource-based view (RBV) focuses on the pooling of resources and/or gaining of access to complementary resources of partners. RBV scholars make predictions on governance structures based on alignment of resources and utilization within the partnership [88,90]. Some analyses indicate that contractual hazards - the focus of TCE - and capabilitiesthe focus of RBV - are interconnected in their influence on governance structures [91]. Complementary views on strategic alliances emphasize further factors such as legitimacy needs [92].

\subsection{Analytic Business Model Framework}

In this study, the retailing of regional electricity is introduced as an "archetype" business model [14]. The archetype can take different forms in practice, leading to distinctive business models (which again form variations) implemented by community energy companies and the marketing partner. For analyzing and comparing different business models, scholars generally use a framework, which describes different organizational elements of a business model as well as the system boundaries of a firm or a firm's network [34,93]. Such a framework provides a meta-model of features, which can be applied to business models in different economic sectors and different contexts [36]. The "business model canvas" based on the work of Osterwalder et al. is one of the most used frameworks [32]. Osterwalder et al. define the following main elements of a business model: value proposition, customer interface, infrastructure, and financial model. Following the argumentation of Brown et al., the "governance" element is added as a separate component to the four 
widely recognized business model elements, as the main focus of investigations lies on the networked character of the regional electricity models [12]. This leads to the following business model framework (Table 1):

Table 1. Analytic business model framework (own compilation and adaptation based on [12,32]).

\begin{tabular}{cl}
\hline Business Model Element & \multicolumn{1}{c}{ Description } \\
\hline Value proposition & $\begin{array}{l}\text { Value of a product or service that a company and its business network provides to the customers } \\
\text { and the wider system; here: regionality and set of further values (see Sections 2.1 and 2.3) }\end{array}$ \\
\hline Customer interface & $\begin{array}{l}\text { Interaction with the customers such as customer relationships, marketing channels, and target } \\
\text { groups (see Section 2.1) }\end{array}$ \\
\hline Infrastructure & $\begin{array}{l}\text { Activities and resources of a company, which are required to deliver the value proposition (see } \\
\text { Section 2.1) }\end{array}$ \\
\hline Financial model & $\begin{array}{l}\text { Relationship between costs incurred to deliver the value proposition to the customer and revenues } \\
\text { generated (see Section 2.1) }\end{array}$ \\
\hline Governance & $\begin{array}{l}\text { Organizational structure of the business (corporate governance) and institutions and organizations } \\
\text { that underpin economic transactions (economic governance) [94] } \\
\text { Here: specific emphasis on interactions and cooperative arrangements with different business } \\
\text { partners spanning a network for delivering value to customers (coordination processes, } \\
\text { relationship management, division of tasks with partners) (see Section 2.4) }\end{array}$ \\
\hline
\end{tabular}

In the following, we use these five elements to describe and distinguish energy business models for retailing regional community electricity.

\section{Methodology}

Because research about regional electricity as a business model for community energy companies is at an early stage, a qualitative exploratory research design was applied $[95,96]$. We combine different qualitative methods in three steps: (1) a literature review and desk research leading to a regional electricity business model typology, (2) semi-structured expert interviews with a selection of community energy companies and intermediaries to collect data on these types, and (3) a focus group workshop, which is used to validate the findings. We chose Germany as the country of research, because the community energy sector is well developed, and a large number of community energy companies offer regional electricity tariffs.

\subsection{Identification of Population and Business Model Typology}

We reviewed the academic literature on regional electricity, community energy, business model innovation, as well as cooperation. Alongside, we carried out a desk research to identify all existent regional electricity products in Germany and to gain an overview of market trends in the field of regional electricity and the players involved. We identified cases using Google as search engine with predefined search terms and websites of identified intermediaries. A total number of 113 electricity tariffs plus 56 peer-to-peer tariffs, which do not yet include energy communities, were identified in a first selection. In 82 out of the 113 cases, we could determine the community energy company involved with certainty. For each tariff, we identified the involved community energy actors and intermediary supplier. We found 26 different intermediary suppliers, including community energy suppliers, large national green energy suppliers, municipal utilities, IT service providers, and peer-to-peer platform providers, all acting as licensed electricity suppliers.

In an iterative process, literature review and desk research led to the classification of three distinctive regional electricity models, which are the basis of the analysis in the following section and the case selection for empirical data collection. 


\subsection{Case Selection and Data Analysis}

After having identified relevant actors, we contacted 37 community energy companies and 15 intermediaries by email. We conducted a total number of 14 semi-structured expert interviews in October and November 2019 (eight community energy companies) and between October 2019 and July 2020 (six intermediaries), respectively. In the following section, quotations from community energy actors are marked as "CE" with an index number and intermediary partners with "IE" and index number. All quotes are own translations from the original German transcripts.

The interview questions were designed to understand the different elements of the business model. We placed emphasis on governance issues, which focused on collaboration and task sharing with the partners. In addition, we asked questions on motives as well as drivers (regulatory, technical, economic, and social) for the business models' development and barriers for adoption. All interviewed community energy companies are organized as energy cooperatives, and retail work is based on voluntary commitment. All have entered different forms of cooperative arrangements with intermediary suppliers to market regional electricity to retail customers. Almost all of the interviewed community energy companies own medium-sized rooftop PV systems; four (also) own and operate wind plants or own shares of them. The operation of generation plants is usually the main source of revenue. The electricity mix of the regional products is $100 \%$ green electricity, most of the companies having a label that certifies this.

We applied a purposive sampling technique for CECs using intermediary and type of regional electricity business model, size of the CEC (number of members, balance-sheet total), and geographical distribution over Germany as selection criteria, weighted in this order. Out of each business model type, at least one community energy company and one intermediary were interviewed. As no CEC had implemented a P2P model at the time of the study, we could conduct no interview on this model with a CEC. We took care that the most important intermediaries as to numbers of identified tariffs were included in the study. The final sample does not include any municipal utility and CEC cooperating with municipal utilities as intermediary, as these did not respond to interview requests.

In addition to the interviews, we held a focus group with 13 representatives from the community energy sector or intermediaries involved in regional electricity models online in May 2020 to be able to deal with selected questions in greater depth. Moreover, we used the workshop to validate first interview results. The group included some of the interviewees from phase 1 and several other representatives.

The analysis of the data was based on qualitative content analysis according to Mayring [97]. Based on our analytical framework and further theoretical considerations, we defined a category system that forms the basis of the qualitative data analysis (see Supplementary S4). We coded interviews by utilising MAXQDA 2018. Based on the category system with additional in-vivo codes, we developed a coding scheme.

\section{Results}

\subsection{Typology of Regional Electricity Business Models}

Building on the findings from the literature on regional electricity products in Germany $[15,20]$ and the findings in the interviews, three regional electricity business models were identified, which differ substantially in their characteristics. All three models have in common that they enable the marketing of locally generated electricity from community RE energy plants to retail customers in the region. In the following, the main distinguishing characteristics are described using the business model framework introduced in chapter 2.5. A comparison of the elements of the three different business models can be found in Table 2 in a summarized form. 
Table 2. Elements of regional electricity business models.

\begin{tabular}{|c|c|c|c|}
\hline & Cooperative Regional Electricity Model & Regional Balancing Pool Model & Peer-to-Peer Model \\
\hline Value Proposition & $\begin{array}{l}\text { Delivering green regional generated } \\
\text { electricity } \\
\text { Optional: delivering citizen electricity } \\
\text { generated from cooperative owned } \\
\text { installations }\end{array}$ & $\begin{array}{ll}\text { - } & \text { Delivering green regional } \\
\text { generated electricity } \\
\text { - } & \text { Promoting an electricity } \\
\text { self-sufficient region }\end{array}$ & $\begin{array}{l}\text { - } \quad \text { Delivering green regional } \\
\text { - } \quad \text { Denerated electricity } \\
\text { selivering electricity from a } \\
\text { specific RE plant, which the } \\
\text { customer can choose }\end{array}$ \\
\hline Customer Interface & $\begin{array}{ll}\text { - } & \text { Members of cooperative as key target } \\
\text { group } \\
\text { - } \quad \text { Customers with regional residency } \\
\text { - } \\
\text { Approximately } 100 \text { to several hundred } \\
\text { customers per tariff }\end{array}$ & $\begin{array}{l}\text { - Customers with residency } \\
\text { in a defined region } \\
\text { Approximately } 100 \text { to } \\
\text { several thousand customers } \\
\text { per tariff }\end{array}$ & $\begin{array}{l}\text { - Costumers with regional or } \\
\text { national residency } \\
\text { Main marketing channel is } \\
\text { the internet P2P platform }\end{array}$ \\
\hline Infrastructure & $\begin{array}{l}\text { - PV and/or wind installations } \\
\text { (minimum size } 100 \mathrm{~kW} \text { ), with a focus } \\
\text { on wind installations } \\
\text { Local marketing to retail end } \\
\text { customers as main activity } \\
\text { Mostly based on voluntary } \\
\text { engagement of cooperative members }\end{array}$ & $\begin{array}{l}\text { - PV, biogas, or wind } \\
\text { installations, with a focus on } \\
\text { small/medium PV } \\
\text { installations balanced in a } \\
\text { regional balancing pool } \\
\text { Plant operator sells local } \\
\text { generated electricity to a } \\
\text { marketing partner via an } \\
\text { electricity trading company }\end{array}$ & $\begin{array}{l}\text { - PV, wind, water, or biogas } \\
\text { installations } \\
\text { The plant operator acts as } \\
\text { the electricity official } \\
\text { supplier } \\
\text { - Most of the electricity } \\
\text { supplier tasks are delegated } \\
\text { to the P2P platform operator }\end{array}$ \\
\hline Financial Model & $\begin{array}{l}\text { - Share of revenue from electricity sales } \\
\text { goes to the cooperative }\end{array}$ & $\begin{array}{l}\text { - In some cases a small share } \\
\text { of electricity sales goes to } \\
\text { plant operator } \\
\text { In most cases no additional } \\
\text { revenue for the plant } \\
\text { operator }\end{array}$ & $\begin{array}{l}\text { - Revenues from electricity } \\
\text { sales are divided between } \\
\text { plant operator and P2P } \\
\text { platform provider }\end{array}$ \\
\hline Governance & $\begin{array}{l}\text { The marketing partner is responsible } \\
\text { for all energy management processes } \\
\text { and electricity supplier obligations } \\
\text { Large national-wide acting partnered } \\
\text { supplier } \\
\text { The energy cooperative is responsible } \\
\text { for local marketing and customer } \\
\text { acquisition }\end{array}$ & $\begin{array}{l}\text { - The main task of the energy } \\
\text { community company lies in } \\
\text { electricity generation } \\
\text { The marketing partner is } \\
\text { responsible for all energy } \\
\text { management processes and } \\
\text { electricity provider } \\
\text { obligations behind the } \\
\text { electricity product } \\
\text { Intermediary supplier with } \\
\text { regional ties } \\
\text { The marketing partner is } \\
\text { mainly responsible for local } \\
\text { marketing }\end{array}$ & $\begin{array}{l}\text { Plant operator is responsible } \\
\text { for billing management } \\
\text { National-wide acting } \\
\text { marketing partner, } \\
\text { managing the technical } \\
\text { complex P2P process } \\
\text { The P2P platform provider } \\
\text { is responsible for almost all } \\
\text { energy management } \\
\text { processes and electricity } \\
\text { provider obligations }\end{array}$ \\
\hline
\end{tabular}

We describe these three business models in more detail in the following, focus on governance structures, and explain some opportunities and challenges as outlined in the interviews.

\subsection{Model 1: The Cooperative Regional Electricity Model}

In this business model, community energy companies with their own RE installations set up a regional electricity product together with a marketing partner and try to retail the electricity tariff to customers in the region. The locally generated electricity usually comes from medium to large PV installations (more than $100 \mathrm{~kW}$ ) or wind power plants, which energy cooperatives operate.

The specific value proposition of the regional product is described as follows: "The question is, do I have a regional actor I trust, where I know that he is locally anchored and that he has an impact on the local level. [ ... ] And the third aspect is the regional origin. I believe, that across these aspects, regional origin is an important additional emotional feature, which convinces people to choose the product." (IE2) 
Hence, the interviewee highlights different facets of regionality: embeddedness in local networks, local impact (i.e., regional value added), and regional origin of the actors, all of which lead to trust in the supplier.

This model offers two different possibilities for the community energy company and its marketing partner to set up a regional electricity product, which both-in comparison to normal electricity tariffs-involve additional financial or administrative efforts. In the first case, the locally generated electricity, or a part of it, is sold directly to the marketing partner. The marketing partner includes this amount of electricity into a regional electricity product, which in general has also other sources of electricity, and retails it to retail customers. In this case, the plant owner-here: the CEC - does not receive a FiP for the electricity according to the German Renewable Energy Source Act (EEG), but a price negotiated with the marketing partner. These negotiated prices generally lie above the average exchange market prices and make the product more costly for the marketing partner. The advantage is that the origin of the electricity is transparent and can therefore be advertised explicitly in the electricity product. The second possibility, applied in most cases, means marketing the locally produced electricity via another trading partner and having paid a FiP to the plant operator for the electricity generated. In this case, the regional origin of the electricity must be proven otherwise, with so called guarantees of regional origin [15]. These prove that a certain amount of locally generated electricity is sold to customers in a specific region. The geographical expansion of the region in which the customers reside is defined by law and covers a $50 \mathrm{~km}$ radius around the RE plant (EEG, Sec. 79a) [20]. The disadvantage of this approach is that procurement of guarantees of regional origin involves an administrative burden and therefore leads to additional costs (IE1).

\subsubsection{Governance}

This business model is often based on long-term partnerships with the marketing partner before setting up a regional electricity product together (CE5, CE6). The marketing partner can also be involved in the founding phase of the energy cooperative, the construction phase of the RE plant, or in trading processes of the electricity generated in the community-owned RE plants. This makes the cooperation by developing a regional electricity product together often easier, because a common understanding already exists (CE5). There are two big marketing partners for community energy companies in Germany, which are present nation-wide and dominate the "cooperative regional electricity model" market segment. "Grünstromwerk GmbH" (now: "naturstrom vor ort $\mathrm{GmbH}^{\text {") }}$ is a subsidiary company of Naturstrom AG, one of the biggest green electricity suppliers in Germany, and is known for its long-time partnerships with community energy cooperatives. "Bürgerwerke $\mathrm{eG}^{\prime \prime}$, organized as an umbrella organization of cooperatives, on the other hand was founded by several community energy cooperatives to realize certain business activities together, especially the retailing of renewable electricity to retail customers. Both "Grünstromwerke" and "Bürgwerke" act in the business model as the licensed electricity supplier and overtake all the regulatory obligations as well as energy management processes necessary to market an electricity product to retail customers. In this role, the marketing partner is responsible for, e.g., customer balancing group management, procurement of residual electricity ("Reststrommenge"), as well as the guarantees of origin (to prove the renewable electricity origin), green electricity labelling, customer switching processes, and customer billing (CE3, IE1, IE2). The governance structure of the business model is shown in a schematic way in Figure 1. The community energy company is mainly responsible for local marketing and acquisition of retail customers (CE4, CE5, CE6). 


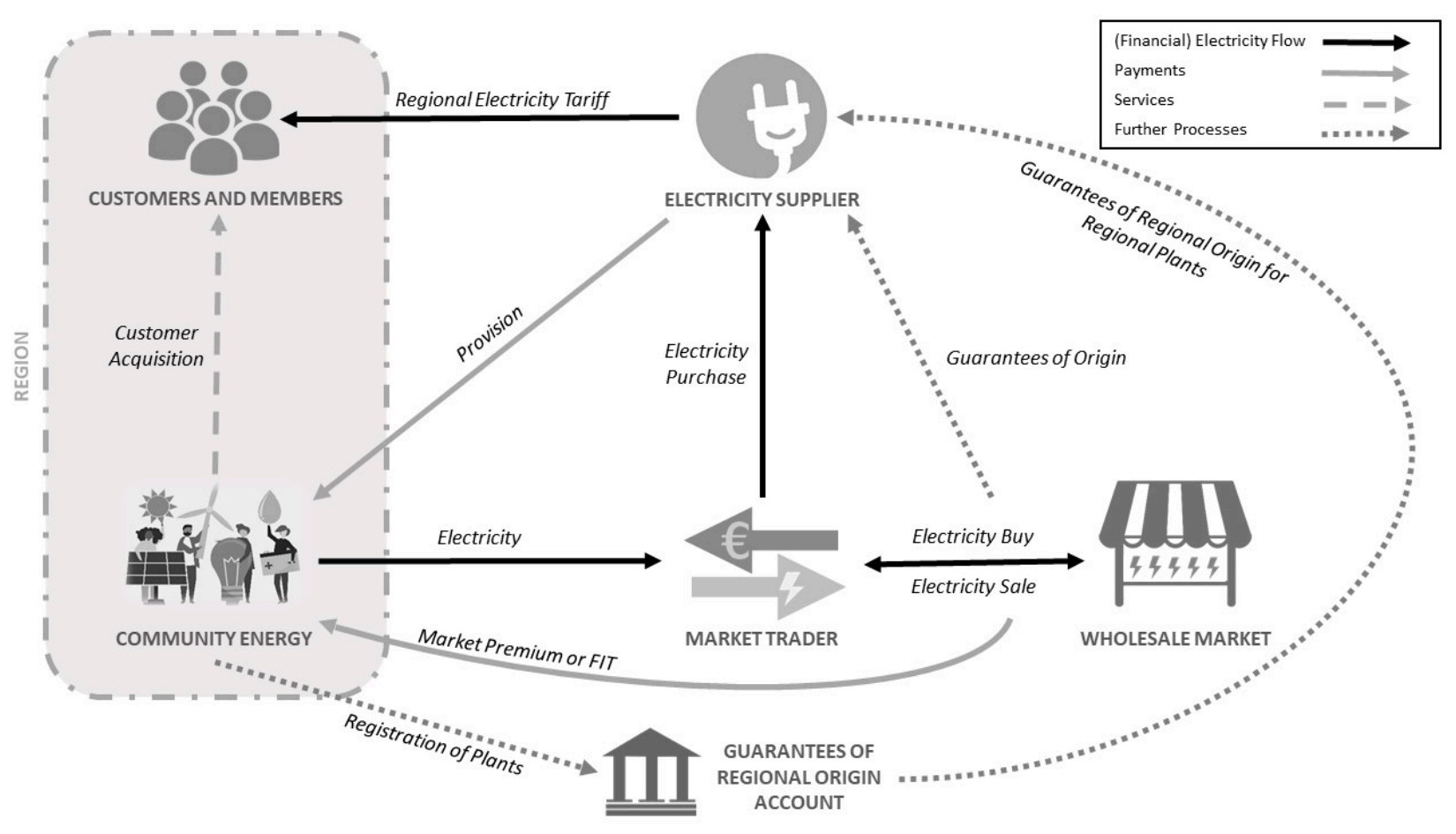

Figure 1. Cooperative regional electricity model with guarantees of regional origin.

"So local marketing really means sales activities on the spot, talking to people, advertising locally, distributing flyers, [ ... ] help to fill out the electricity contracts and forward them." (CE5)

However, the marketing partner supports the community energy company by offering customized product websites and supporting marketing events. Since the marketing partner is the official electricity supplier, the community energy company receives its revenue from the sale of electricity from the marketing partner. It is usually paid in the form of a provision, which is based on $\mathrm{kWh}$ sold. As the marketing partner is responsible for most of the related business model activities and tasks, the main economic value stays there. The community energy company just receives a rather small share (CE3, CE4, CE5, CE6). Nevertheless, the model is described as a collaborative approach, since essential marketing characteristics, often also the electricity retail price or market appearance, are negotiated together, and the involved community energy company has to put a relatively large amount of their own work into developing the product (CE3, CE4, CE5).

\subsubsection{Opportunities and Challenges}

A few interviewed community energy companies aim to use the additional revenue from electricity sales as a relevant future pillar of finance (CE6). At this point, however, the amount of customers are too small in all interviewed cases for the community energy company to realize significant profits. So far, the work for local marketing of the electricity product is based on the voluntary commitment of individual members of the cooperative. With a customer base limited to the region, the development of professional structures in the cooperative for local marketing is not likely (CE5). The main objective for cooperatives in developing a regional electricity tariff is therefore not a financial one (CE2, CE5). Most of the interviewed companies expect regional electricity tariff to increase awareness of renewable energies among local citizens (IE2, CE5).

"The [regional electricity product] is an essential vehicle to create acceptance for the decentralized energy transition and to anchor it democratically a little bit, so that not every renewable energy plant is immediately opposed by a citizens' initiative." (IE1)

Thus, community energy companies hope for an increased public acceptance in the case of planned constructions of renewable energy plants in the region (IE 1, CE5). 
Partnerships with energy suppliers have also created a growing network of cooperatives that is regarded as a co-learning field for future market changes, such as expiring FiT schemes (CE1, CE2, CE3, IE1, IE2).

"Through the development of the 'Bürgerwerke' we are strongly interconnected with other energy cooperatives and these connections are extremely important. So, what is happening on a second level is extremely beneficial for all involved." (CE2)

For the marketing partner, on the other hand, the access to local citizens, which they could not reach without the local cooperative, is regarded as additional value (IE1).

"We are already trying to get into the regional networks thematically [...] and this via the cooperatives via the members of the cooperatives and to address their local multipliers." (IE1)

For the marketing partner, one of the main obstacles is high transactions costs, since the regional certification process and setting up tariffs for rather small customer groups is relatively costly (IE1).

\subsection{Model 2: The Regional Balancing Pool Model}

In this model, a local renewable energy supplier takes the leading role and sets up a regional electricity product, in which mostly small to medium sized PV, biomass, and large sized wind installations are integrated. The owners of the RE plants can be energy cooperatives. In reality, however, mostly individuals, SMEs, or municipal suppliers own the plants. The regional renewable energy capacities are aggregated and balanced via a separate regional balancing pool. The energy supplier provides the technical infrastructure, sets up the balancing pool, and defines its geographical expansions.

"The main difference in this model is that we register and manage a separate project balancing pool or distribution balancing pool for each regional electricity project." (IE3)

This makes it possible to match local generation and electricity consumption of retail customers who live in the area covered by the balancing pool. In this model, it is transparent for consumers which RE plants are part of the electricity product, and the regional balancing group verifies the regional origin of the electricity. The main value proposition of this model is seen in the transparent balancing of production and consumption in a region: "We want to address specifically the topic of regional origin, regional generation and regional consumption [ ... ] we want to emphasize the regional concept." (CE7)

\subsubsection{Governance}

The findings of the desk research and interviews show that in most of the existing cases of this business model, community energy companies play only a minor part (IE4). In theory, the local community energy company could overtake three roles: In the first case, which exists in most cases in reality, the local community energy company markets its generated electricity through an intermediary energy supplier. The supplier often has local ties and its headquarters in the region. This supplier aggregates the RE capacities of the community energy company and other regional plant operators into the regional electricity product via the regional balancing pool. However, the community energy company is not involved in the design of the electricity product, is usually not much involved in local marketing, and does not receive any additional revenues, besides revenues from the FiT/FiP scheme (IE4). In the second much less frequent case, the community energy company is actively involved in the retail process of the locally generated electricity to customers (CE7). For this, however, it needs a professional marketing partner who takes over all regulatory obligations of the electricity supplier and covers the energy management processes necessary to set up an electricity product.

"This is only possible with a partner, i.e., in terms of know-how and processing [...] from the handling of the technology and the software one can probably not handle it as a community energy cooperative, which is managed voluntarily. In principle, it goes beyond the scope of any given task. And that's why you can only do it with a partner." (CE7) 
The partnered supplier is also responsible for the management of the regional balancing group (IE3). The community energy company is mainly responsible for the acquisition of retail customers and local marketing (CE7). In that case, it is getting a small share of the revenues of electricity sales from the marketing partner. In the third case, the regional community companies (and other citizens) own shares of the electricity supplier in charge, which could be organized as a cooperative (IE5). In this case, the electricity supplier is managed separately and has professional structures.

The governance of the "regional balancing pool model" is shown in Figure 2 in a schematic form. In most cases, this model is realized in a top-down approach, where (local) electricity suppliers win community energy companies or other actors with RE plants over to market their electricity. Almost all economic value stays on the side of the (local) electricity supplier.

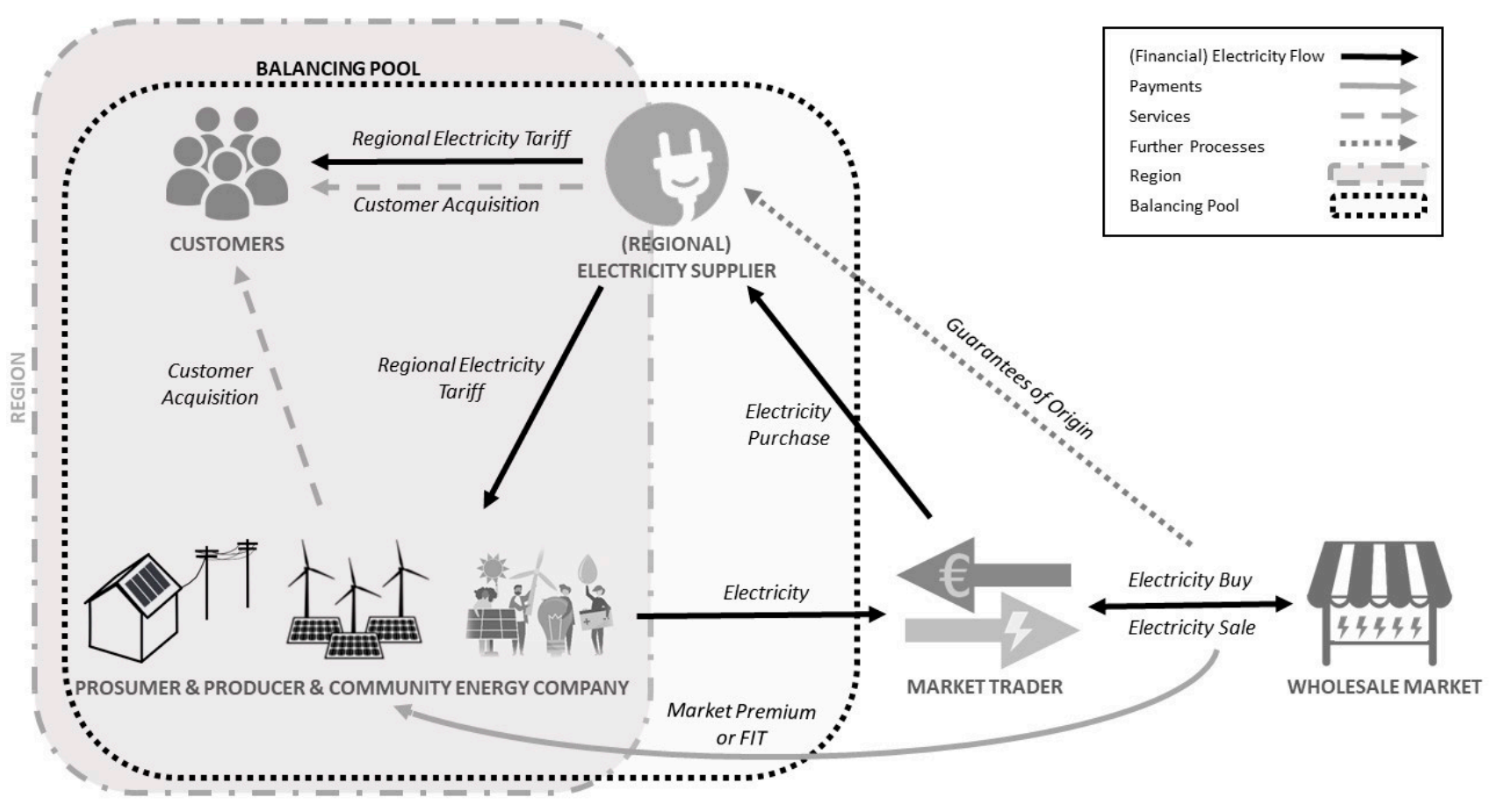

Figure 2. Regional balancing pool model.

\subsubsection{Opportunities and Challenges}

Because of the matching of generation and consumption in a separate balancing pool, no guarantees of regional origin (see above) have to be purchased to verify the regional origin of the electricity product (IE3, IE4). On the other hand, this makes the model technically more sophisticated, and it relies on the aggregation of several (small) RE plants, which raises transaction costs (IE5). It is a scalable model, as new RE plants can be integrated comparably easily (IE3). Thus, it is suitable also for RE plants, whose FiT support scheme runs out in the coming years, if a regional electricity product exists in the plant's region (IE3, IE4, IE5). This also makes it interesting for community energy companies that want to continue operating their plants when the FiT support schemes expire. The interviews show that in this model, the electricity suppliers are in direct competition with local public utilities (CE7, IE3) - probably more so than with the other two business model types, as the product differs only slightly from the one supplied by local utility companies, and consumers regard the latter as "regional" as well. Therefore, the model is particularly successful if there is no strong local incumbent. The necessary tool of the regional balancing pool enables the measurement and visualization of how electricity self-sufficient a region can be (IE3, IE4, IE5). 
One intermediary supplier regards the model as an experimentation field for sociotechnological innovations, working together with prosumers and marketing their excess electricity (IE5). Through the installation of smart meters and smart management systems, a potential for the use of flexibility options in the region may be realized (IE5). The additional introduction of time-of-use tariffs has the potential to incentivize demand side management in households (IE5). By combining several innovations, an economic optimum for the use of electricity in a regional producer-consumer community should be achieved in the future (IE5). Like the model before, the diffusion of the model is put in the context of increasing awareness of local citizens for energy transition topics (IE3, CE7).

\subsection{Model 3: Peer-to-Peer Model}

In Germany, there is so far one established P2P model where retail customers can purchase a green electricity tariff directly from renewable electricity plant operators. The P2P model relies on an internet platform as a market place to bring renewable plant operators and retail customers together. Several plant operators offer electricity tariffs with electricity from medium to large size PV, wind, biomass, or waterpower installations on the P2P internet platform. Usually, for each RE installation, a separate tariff is offered. So far, no CEC in Germany has collaborated with the platform and offers an electricity product there, but this is planned for the future, as P2P business models are theoretically considered suitable for CECs (IE6). The P2P business model is not a strictly regional electricity model, as the tariffs are not limited to a customer base from a certain region. However, the findings of the interviews suggest that more than $50 \%$ of the customers live in proximity to the specific RE plant location (IE6), which is why this model is integrated into this study. For the customers, it is completely transparent from which operator and which plant they receive their electricity.

\subsubsection{Governance}

The unique characteristic of this model is that the system operator also becomes an official electricity supplier and stands in a direct contractual relationship with the retail customer.

"In other words, the plant operator himself becomes an electricity supply company with all relevant registrations with all authorities and duties as transmission and distribution network operators." (IE6)

This fact makes the transparency of the electricity origin possible in the first place. Still, the platform operator takes over most of the related obligations of electricity supplier, as plant operators usually do not have the resources for these complex tasks. This includes registration with regulators, distribution grid operators, and transmission grid operators, customer-switching processes, managing residual electricity, and other tasks necessary to retail an electricity product. As the peer-to-peer platform operator is managing several electricity tariffs simultaneously, this is only possible through sophisticated and mostly automated processes (IE6). The plant operator partly takes over the task of retail customer billing, as this task cannot be completely delegated. The business model can be described as organizationally complex, as more actors like an electricity trading company are involved directly, which leads to considerably higher transaction costs (IE6). In an automated process, set up by the $\mathrm{P} 2 \mathrm{P}$ platform operator, the market trader has to match the generation of electricity of a respective RE plant (in a 15-min interval) and the consumption of retail customers (standard load profile) (IE6).

"We actually match generation and consumption. So the electricity that is delivered to the end customer is precisely controlled whether the electricity was also generated in the plant at the same time." (IE6)

The governance of the peer-to-peer model is shown in Figure 3 in a schematic way. How strongly the plant operator is involved in local marketing varies, but most customers are acquired via the internet platform as the main marketing channel (IE6). Plant operators have relatively high participation options, as they have influence on the retail price and 
market appearance (IE6). The plant operator obtains a revenue, additional to the FiP, as a share of the retail price (IE6). However, a large part of the revenues from retailing also goes to the platform operator as remuneration for the various offered services. As plant and platform operator both take responsibilities, the approach is best described as a top-down approach with collaborative elements.

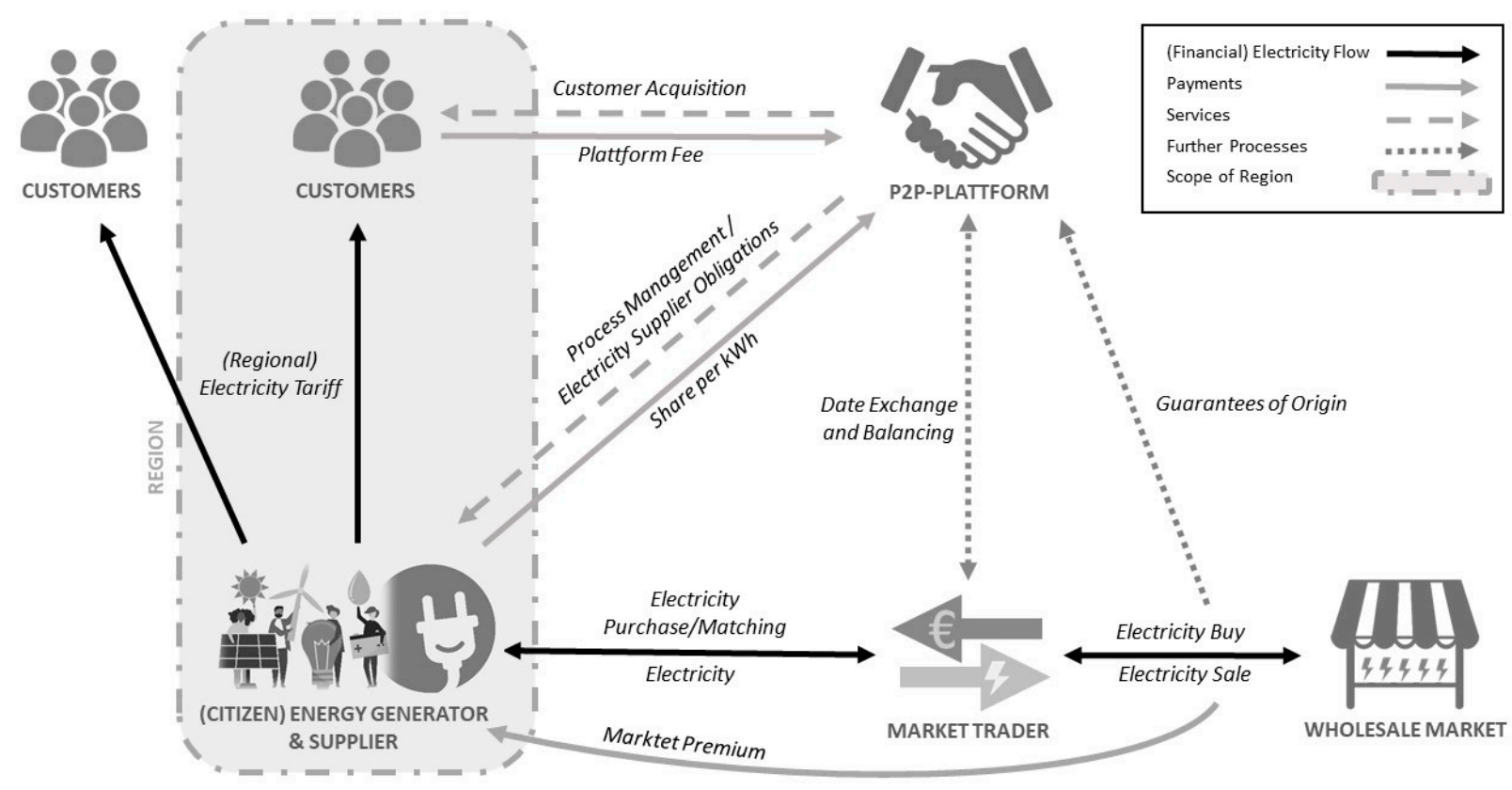

Figure 3. Peer-to-peer model with retail customers in RE plant region.

\subsubsection{Opportunities and Challenges}

Compared to the other two models described above, the P2P model offers the most potential for additional financial revenue for the community energy company (plant operator).

"The peer-to-peer platform cuts out the electricity supplier that is normally behind it. Therefore, it directly offers the plant operators the possibility to get the margin that would normally be put in by the Vattenfall companies or e.on or the public utilities themselves. Thus, the revenue goes directly to those who operate the plants and build new ones." (IE6)

On the other side, the amount of work and responsibility for the plant operator is higher. This model is relatively well suited for a post feed-in era, as it enables plant operators to continue operation viably. In addition, it can be implemented relatively quickly in collaboration with an existing P2P platform operator. This could prevent old plants from being dismantled, when support schemes are ending. It also does not require any significant additional competences to be learned by the plant operator, even though the latter takes on the role of the legal electricity supplier. Successful local customer acquisition can be a challenge, since both the platform operator and the plant operator need to create trust among local inhabitants in order to gain new customers (IE6). The model is based on several technical and organizational innovations, which enable P2P trading despite legally demanding requirements. The model will be easily scalable and therefore will be able to reduce currently high transaction costs for the platform provider in the future, if the customer base increases.

\section{Discussion}

Having described the results of desk research, interviews, and the focus group, we organize our discussion of these results according to the three research questions: First, we summarize findings on the types of business models. Second, we explore the governance structures identified in the three types of business models in greater detail. Third, we 
derive implications and discuss how CECs' regional electricity models can contribute to the energy transition process. Although our analysis refers to Germany, some of the discussion points listed here are also transferable to other countries with regional electricity models (e.g., UK or Netherlands) (e.g., [23]). Due to different regulatory frameworks, the models in other countries differ significantly. However, explanations on governance aspects and cooperations as well as general findings on community business models are equally relevant in other country contexts.

\subsection{Current Business Models in Electricity Retailing for CECs}

Our results suggest that there are three different regional electricity models that integrate electricity from community energy power plants into a regional electricity tariff. The governance structures of these models differ considerably. We discuss the differences in greater detail in the next sub-section. Our results show that the governance element is central to the business models, because it shapes the business ecosystem and can function as a driver for business model innovation.

The value proposition of the three models is similar, as it emphasizes community energy and regionality. However, how the regionality of the electricity product is established differs between the models. The differences in the customer segments are mainly characterized by the fact that in Model 1, members of the cooperative are the main customer target group, and local marketing is mainly executed by the cooperative itself. In Model 2, on the other hand, the intermediary takes over the main part of local marketing. Model 3 does not exclusively address customers in the region; the national customers are mainly acquired via the P2P platform. One advantage of Model 2 is that smaller RE systems, such as rooftop PV systems (less than $100 \mathrm{~kW}$ ), can be relatively easily integrated into a regional electricity product. However, this requires a smart meter infrastructure. In practice, several plants in a range of $20-40 \mathrm{~kW}$ are integrated into regional electricity products via Model 2. Looking at the financial model, we see that Model 3 in particular, and Model 1 to a lesser extent, can generate additional revenue streams for the CEC, although revenues will always be limited, because a large part goes to the intermediary and the number of customers is limited. Model 2 is currently still based almost exclusively on revenue from FiT or FiP.

Currently, Model 1 is the type of business model most frequently used by CECs. Two intermediaries that have entered alliances with various energy cooperatives are mainly driving the spread of this model. As one of these intermediaries is an umbrella cooperative with close links to its member cooperatives and the other is actively engaging in the community energy sector, this uneven distribution among the models is not surprising. Models 2 and 3 are in principle also suitable for CECs, but are not exclusively focused on them, as individual citizens or prosumers with RE plants are the main participants so far. Hence, one can derive from the data, which we collected, that the choice of model is mainly driven by and through the intermediary.

Regional electricity models compete with the incumbent utility model that also offers green electricity products to customers. A market analysis that examines the potential future market share of regional electricity models compared to the incumbent utility model is beyond the scope of this study. All three models have so far only managed to capture small market shares. One main reason is that regional electricity products compete with several other green electricity products (from cross-regional big green electricity suppliers and municipal utilities), and the willingness of electricity customers to switch is generally low [19]. Since various regional electricity products of Models 1 and 2 have existed for a few years, they have already been able to reach larger customer groups compared to the P2P model. Like in other European Countries, the P2P model in Germany remains in a pioneer phase so far [23]. There is only one commercial P2P model in Germany, and it remains to be seen to what extent it will match customer preferences and reach larger customer groups. Compared to Models 1 and 2, however, the P2P model has the potential to scale easily, as one platform provider can theoretically accept a large number of community energy plant operators as electricity providers. 


\subsection{Governance Structures with Focus on the Cooperation between CECS and Intermediaries}

All three regional electricity models have in common that legal, commercial, financial, and technical expertise is shared between CECs and an intermediary through framework arrangements to de-risk the complex business activity and create replicable business models for local community energy companies [11]. This result is in line with general findings from research on community energy $[2,9,11,16,76]$, showing that CECs usually require a business partner for facilitating sophisticated business models in the energy sector. As this study shows, this is especially true for retailing regional electricity to customers because of the complex legal issues involved and the currently weak economic viability. CECs usually build on voluntary work [25]. Therefore, they cannot provide the necessary resources or capacities-especially time, expertise, and financing-and technical infrastructure to fulfil the role as the licensed electricity supplier to sell electricity to customers. Therefore, strategic alliances with different types of electricity suppliers are established, which lead to a networked nature of value creation process and interdependent business activities.

Following Nolden et al.'s explanations of intermediary arrangements, different transaction costs ("search and haggling costs", "bargaining costs", "opportunism costs") are lowered through these standardized framework arrangements in the different models [11]. As our study shows, however, feasibility relies on economies of scale. Moreover, transaction cost theory alone cannot explain the choice between the different models or partners or why regional electricity products evolved in the first place, because transaction costs are significantly higher in all three models compared to normal green electricity tariffs. Against this background, some authors combine TCE and resource-based view to analyze strategic alliances. Following a resource-based perspective, the alliances identified can create synergies between the resources of the CEC and the partner firm, enabling market access and enhancing the market performance substantially [88].

In addition to TCE and RBV arguments, legitimacy needs [92] of intermediaries also play a role in explaining the formation of these strategic alliances. In this respect, interviewees highlighted specifically the need to include local communities to make the product authentic. Following [98,99], Eggers et al. [100] conceptualize brand authenticity as consisting of brand consistency, customer orientation, and congruency. In this sense, intermediaries especially use alliances to create consistency. A resource-based perspective can also provide explanations for how the resources of the partnering firms are shared to gain market access [88]. There are significant differences between the identified models in terms of governance structure and degree of cooperation between CEC and intermediary supplier. Depending on the model, the CECs either take a very active role in the business model or are barely involved in the business activities. As the empirical analysis has shown, Model 1 (cooperative regional model) is a collaborative approach. The intermediaries not only provide the infrastructure of the electricity supplier, but also help to expand the capacities of the CECs. The capacity building efforts include, for example, sales training, assistance in designing the marketing presence, and access to a professional network. In this sense, CECs benefit from the professional structures and expert knowledge of intermediaries, which enables CECs to participate actively in the process of local retailing of the generated electricity and gain addition revenues.

The intermediary, on the other hand, benefits from the local network, local knowledge, and the sales activities of the CECs executed by volunteers. CECs are better suited to reach local retail customers due to their recognition in the region and personal contacts within the local population. For Model 3 (P2P model), the collaborative character of the business relationship only partially applies. The intermediary manages the complex technical infrastructure and takes over most of the tasks and duties of a licensed energy supplier. In addition, CECs use the marketing brand of the intermediary. On the other hand, CECs utilize their local contacts to acquire customers. Usually, the CECs are not actively supported through capacity building. A different governance approach is pursued in Model 2 (regional balancing pool model). Here, CECs act mainly as plant operators and are only marginally integrated into the retailing process, whereas the supplier takes the 
leading role. This results in a top-down governance approach. This model is therefore more suitable for CECs or citizens, who are looking for as little additional work as possible to market their electricity in the region. However, there are emerging models, in which community-owned electricity suppliers develop regional electricity pool models and form a strong partnership with regional CECs, similar to Model 1.

Many energy cooperatives using Model 1 for regional electricity marketing are organized in a national umbrella cooperative, which takes on the role of the electricity supplier. As Warbroek et al. show, through the institutional infrastructure of the umbrella cooperative, the development of the member cooperatives is promoted in different forms (capacity building, reduction of barriers, or fostering of business activities). Moreover, it enables a partnership at a level playing field [16]. Furthermore, the umbrella organization supports the exchange between member cooperatives, which facilitates a mutual learning process in the field of regional electricity marketing and helps to diffuse knowledge and innovation in this sector $[2,76]$.

Compared with findings on UK community energy and intermediaries by Hargreaves et al. [76] or Seyfang et al. [2], our results show that the partnerships between intermediaries and CECs in regional electricity models in Germany are considerably more professionally structured, and the networked business activities are in the process of leaving niches. The interviewed professional intermediaries usually share the goals and ideas of community energy actors and can thus influence policy makers, government bodies, and key market actors through their networks to spread the concept of community energy [16]. The intermediary not only takes on the role of a broker and facilitator, but also provides CECs with the capacity to compete in the highly competitive retail electricity market. As other authors have pointed out, our empirical findings show that trust [89] and commitment [88] play a major role for the success of the partnerships. Such partnerships, which already existed before the joint development of a regional electricity product (e.g., in the construction phase of the generation plant), are advantageous, because in general a high degree of trust exists, which strengthens the commitment, and the parties involved can rely on each other in sharing tasks and duties. Moreover, both intermediaries that dominate in Model 1 share similar philosophies as CECs, as the first is an umbrella organization of cooperatives and the other holds tight networks in the community energy sector as well. As a result, trust through iterative interactions between partners and closeness of philosophies build the main reasons for CECs to choose specific intermediaries.

\subsection{Relevance for the Transition Process}

Regional electricity models are a fertile ground for technological, organizational, and social innovation [36]. They have the potential to actively influence their surrounding ecosystem by shaping local energy transition processes and to create value for the CEC, the partnering intermediary, and the wider energy system. Our findings show that they create not only economic, but also environmental and social value. Currently, regional electricity models (besides other prosumer models) are the only market instrument in Germany to balance and link regional renewable electricity generation and consumption within a region. By spatially linking renewable generation capacities and the consumption of the local population, regional electricity products offer a unique value proposition compared to normal green electricity products $[14,19]$. In all three presented models, the renewable electricity sources can be traced back to single or multiple regional renewable energy plants in a transparent way. As the findings from the interviews show, regional electricity products establish a comprehensible and tangible link for customers to where their electricity comes from. For the wider energy system, the value of regional electricity models can also be found in the spatial proximity of production and consumption. These models can be regarded as a first step to local electricity markets. In future, these models could be used in combination with time-of-use (TOU) tariffs, giving regional price signals in real time and enabling demand-side management [12,101]. If regional electricity tariffs are combined with TOU tariffs, peak shaving effects could occur, as customers are incentivized 
to reduce consumption in times of high network stress [101]. However, TOU tariffs demand a smart-meter infrastructure, which is only just being rolled out in Germany. Moreover, studies show that the use of TOU tariffs is often rather unattractive for customers from a pure financial point of view [102]. Creating a desirable effect at the distribution grid level would require a critical mass of customers, which currently none of the models studied achieve.

As the empirical data of our study show, all interviewed CECs expect that regional electricity models contribute to their goals concerning a local energy transition. We identify two main motives here: First, CECs expect that with a regional electricity product, their visibility in the local population is higher, leading to increasing awareness and acceptance for their mission and goals. For all interviewed CECs, this is an important aspect, as the acceptance among the population is a basic prerequisite to plan and build new renewable energy plants [103-105]. As Friege and Herbes state, building trust and awareness is also crucial for the marketing success of the product [106]. Second, the regional electricity models are regarded as a learning field for the time when public support schemes expire and plants have to operate in the market without FiT or FiP. With current market prices for electricity, it is not feasible to operate RE plants after FiT/FiP schemes have ended, because maintenance costs would exceed revenues [11,15]. Retailing to customers can generate additional revenue that will allow CECs to continue operating without support scheme. These models could thus help to reduce the number of post-FiT plants being dismantled. All three identified regional electricity models are theoretically viable for plant operation without FiT/FiP and can therefore contribute to preventing the deinstallation of old RE plants.

The development of regional electricity products brings up a number of social or organizational innovations that support the community-led energy transition. Joint business models strengthen partnerships and create professional business networks, leaving room for further business model innovations. Findings from desk research illustrate the important role that "Bürgerwerke" plays as national community energy supplier. Moreover, the interview results highlight the additional functions for business model innovation and further development of CECs that this intermediary fulfils. At the regional level, several new small suppliers have emerged, cooperating with CECs and taking over the role of the main green energy supplier for the region. In addition, a number of other actors, with various functions, are involved in the business models spanning together an innovation network. These are municipal utility companies that supply residual electricity, IT service companies that provide the technical infrastructure for such models, or market traders that handle the trading of surplus electricity in the background. In addition, CECs are also active in other innovative business areas and are involved in tenant-to-landlord electricity models, where they cooperate with real estate companies or municipalities. The establishment of new business models, such as regional electricity models, creates networks of different actors who can contribute to the transformation process of the energy system through technical, organizational, or social innovations for sustainable system transformation at different levels [35,36]. This development can increase overall resilience of community energy structures and help to diffusion goals and mission of community energy [2]. The relative importance of these different business models for the community energy sector and its impact on the energy transition is a desideratum for research.

\section{Conclusions}

The study identifies three distinctive regional electricity models, which enable community energy actors to retail electricity to customers close to its place of generation. All three models differ in technical and organizational functionalities, are suitable for different community energy actors and set different priorities in the value proposition. The interdependent business arrangements with intermediary suppliers is decisive for all models. The collaboration of community energy companies with local or cross-regional electricity suppliers creates cooperation and networks that can be incubators for further sustainable 
innovations. The literature on local electricity business models and the empirical findings highlight different forms of value, promoting local community energy installations or the democratization of energy systems [14,17]. For several community energy companies, the sale of regional electricity offers a viable business model. The main motives are to increase their own local visibility and gain local acceptance, rather than economic motives. Many interviewees of community energy companies see them as a learning field for technological, organizational, and social innovations that contribute to experimenting with energy business models for upcoming challenges.

Through the proximity of generation and consumption, regional electricity models could provide additional system benefits, if a critical amount of customers would switch to regional tariffs. However, the study shows that although there are now over a hundred regional electricity tariffs with community actors involved in Germany, the number of customers is still relatively low. The main reason is seen in the hindering regulatory framework conditions for regional electricity retail. There are no financial incentives for retail customers to switch to a regional electricity tariff in Germany. Retail customers pay the same network charges, fees, and levies as for conventional tariffs. However, for the intermediary supplier, who has to meet the regulatory requirements for regional electricity products, transaction costs are much higher and the customer base much smaller compared to normal green electricity tariffs. The guarantees of regional origin have to be purchased, or the regional origin has to be established using relatively complex technical tools. This reduces competitiveness in a highly contested electricity retail market. Under the current regulatory conditions and grid charging mechanisms, regional electricity marketing is hindered instead of incentivized and offers no financial benefits for generators, suppliers, or retail customers.

If policy makers do not make the necessary regulatory changes and acknowledge the particular value proposition of regional electricity, regional electricity products will not be able to play a decisive role in the future. However, the networks and cooperation that have emerged in this context can remain and continue to be drivers and promoters of a sustainable energy system transformation. While, as shown, business model innovation can capture new values, the effects of further diffusion of regional electricity models to the wider energy system are uncertain. Further research should examine the creation of value through cooperation and networks in local electricity models in more detail. In addition, economic studies are necessary to determine when economies of scale compensate high transaction costs in regional electricity models.

Supplementary Materials: The following are available online at https://www.mdpi.com/2071-1 050/13/4/2241/s1: Table S1: Regional Electricity Tariffs in Germany, S2: Key Interview Questions Community Energy, S3: Key Interview Questions Intermediaries, S4: Codebook.

Author Contributions: M.E. led the conceptualization with the help of L.H.; T.B., M.E., and L.H. collected empirical data and conducted the data analysis; M.E. wrote Sections 1, 3, 4 and 6; M.E. and L.H. wrote Sections 2 and 5; T.B. visualized the figures; L.H. and T.B. conducted the internal review and editing process. All authors have read and agreed to the published version of the manuscript.

Funding: This research was funded by the European Commission Horizon 2020 project: PROSEUProsumers for the Energy Union, grant agreement number 764056.

Institutional Review Board Statement: The study was approved by the Ethics Committee of Leuphana University Lüneburg (date of approval: 14 May 2019).

Informed Consent Statement: Informed consent was obtained from all subjects involved in the study.

Data Availability Statement: Desk research data is available in Supplementary "S1: Regional Electricity Tariffs". Interview transcripts are not publicity available for reasons of confidentiality.

Acknowledgments: The authors would like to thank all the interviewees and focus group participants. Support with data collection by Alina Beigang is gratefully acknowledged. 
Conflicts of Interest: The authors declare no conflict of interest. The funders had no role in the design of the study; in the collection, analyses, or interpretation of data; in the writing of the manuscript; or in the decision to publish the results.

\section{References}

1. Geels, F.W. Disruption and low-carbon system transformation: Progress and new challenges in socio-technical transitions research and the Multi-Level Perspective. Energy Res. Soc. Sci. 2018, 37, 224-231. [CrossRef]

2. Seyfang, G.; Hielscher, S.; Hargreaves, T.; Martiskainen, M.; Smith, A. A grassroots sustainable energy niche? Reflections on community energy in the UK. Environ. Innov. Soc. Transit. 2014, 13, 21-44. [CrossRef]

3. van der Schoor, T.; Scholtens, B. Power to the people: Local community initiatives and the transition to sustainable energy. Renew. Sustain. Energy Rev. 2015, 43, 666-675. [CrossRef]

4. Koirala, B.P.; Koliou, E.; Friege, J.; Hakvoort, R.A.; Herder, P.M. Energetic communities for community energy: A review of key issues and trends shaping integrated community energy systems. Renew. Sustain. Energy Rev. 2016, 56, 722-744. [CrossRef]

5. Walker, G.; Devine-Wright, P. Community renewable energy: What should it mean? Energy Policy 2008, 36, 497-500. [CrossRef]

6. Kahla, F.; Holstenkamp, L.; Degenhart, H. Entwicklung und Stand von Bürgerenergiegesellschaften und Energiegenossenschaften in Deutschland. In Arbeitspapierreihe Wirtschaft \& Recht; Leuphana University Lüneburg, Institute of Finance and Accounting: Lüneburg, Germany, 2017.

7. Yildiz, Ö.; Rommel, J.; Debor, S.; Holstenkamp, L.; Mey, F.; Müller, J.R.; Radtke, J.; Rognli, J. Renewable energy cooperatives as gatekeepers or facilitators? Recent developments in Germany and a multidisciplinary research agenda. Energy Res. Soc. Sci. 2015, 6, 59-73. [CrossRef]

8. Holstenkamp, L.; Kahla, F. What are community energy companies trying to accomplish? An empirical investigation of investment motives in the German case. Energy Policy 2016, 97, 112-122. [CrossRef]

9. Herbes, C.; Brummer, V.; Rognli, J.; Blazejewski, S.; Gericke, N. Responding to policy change: New business models for renewable energy cooperatives-Barriers perceived by cooperatives' members. Energy Policy 2017, 109, 82-95. [CrossRef]

10. Yildiz, Ö. Financing renewable energy infrastructures via financial citizen participation-The case of Germany. Renew. Energy 2014, 68, 677-685. [CrossRef]

11. Nolden, C.; Barnes, J.; Nicholls, J. Community energy business model evolution: A review of solar photovoltaic developments in England. Renew. Sustain. Energy Rev. 2020, 122, 109722. [CrossRef]

12. Brown, D.; Hall, S.; Davis, M.E. Prosumers in the post subsidy era: An exploration of new prosumer business models in the UK. Energy Policy 2019, 135, 110984. [CrossRef]

13. Beermann, J.; Tews, K. Decentralised laboratories in the German energy transition. Why local renewable energy initiatives must reinvent themselves. J. Clean. Prod. 2017, 169, 125-134. [CrossRef]

14. Hall, S.; Roelich, K. Business model innovation in electricity supply markets: The role of complex value in the United Kingdom. Energy Policy 2016, 92, 286-298. [CrossRef]

15. German Environment Agency. Marktanalyse Ökostrom II. Marktanalyse Ökostrom und HKN, Weiterentwicklung des Herkunftsnachweissystems und der Stromkennzeichnung; Umweltbundesamt: Dessau-Roßlau, Germany, 2019.

16. Warbroek, B.; Hoppe, T.; Coenen, F.; Bressers, H. The Role of Intermediaries in Supporting Local Low-Carbon Energy Initiatives. Sustainability 2018, 10, 2450. [CrossRef]

17. Hiteva, R.; Sovacool, B. Harnessing social innovation for energy justice: A business model perspective. Energy Policy 2017, 107, 631-639. [CrossRef]

18. Parag, Y.; Sovacool, B.K. Electricity market design for the prosumer era. Nat Energy 2016, 1, 329. [CrossRef]

19. Kalkbrenner, B.J.; Yonezawa, K.; Roosen, J. Consumer preferences for electricity tariffs: Does proximity matter? Energy Policy 2017, 107, 413-424. [CrossRef]

20. Peters, P.C.; Madlener, R.; Schemm, R. Potenziale zur Erhöhung des regionalen Markenkerns im Stromvertrieb am Beispiel der regionalen Grünstromkennzeichnung gemäß EEG 2017. Z. Energ. 2018, 42, 35-55. [CrossRef]

21. Brown, D.; Hall, S.; Davis, M.E. What is prosumerism for? Exploring the normative dimensions of decentralised energy transitions. Energy Res. Soc. Sci. 2020, 66, 101475. [CrossRef]

22. Gui, E.M.; MacGill, I. Typology of future clean energy communities: An exploratory structure, opportunities, and challenges. Energy Res. Soc. Sci. 2018, 35, 94-107. [CrossRef]

23. Hall, S.; Brown, D.; Davis, M.; Ehrtmann, M.; Holstenkamp, L. Business Models for Prosumers in Europe. PROSEU-Prosumers for the Energy Union: Mainstreaming Active Participation of Citizens in the Energy (Deliverable ND4.1); PROSEU: Leeds, UK; Lüneburg, Germany, 2020. [CrossRef]

24. Kalkbrenner, B.J.; Roosen, J. Citizens' willingness to participate in local renewable energy projects: The role of community and trust in Germany. Energy Res. Soc. Sci. 2016, 13, 60-70. [CrossRef]

25. Horstink, L.; Wittmayer, J.M.; Ng, K.; Luz, G.P.; Marín-González, E.; Gährs, S.; Campos, I.; Holstenkamp, L.; Oxenaar, S.; Brown, D. Collective renewable energy prosumers and the promises of the energy union: Taking stock. Energies 2020, 13, 421. [CrossRef]

26. Wilkinson, S.; Hojckova, K.; Eon, C.; Morrison, G.M.; Sandén, B. Is peer-to-peer electricity trading empowering users? Evidence on motivations and roles in a prosumer business model trial in Australia. Energy Res. Soc. Sci. 2020, 66, 101500. [CrossRef] 
27. Diaz-Rainey, I.; Ashton, J.K. Profiling potential green electricity tariff adopters: Green consumerism as an environmental policy tool? Bus. Strat. Env. 2011, 20, 456-470. [CrossRef]

28. Tabi, A.; Hille, S.L.; Wüstenhagen, R. What makes people seal the green power deal?-Customer segmentation based on choice experiment in Germany. Ecol. Econ. 2014, 107, 206-215. [CrossRef]

29. Herbes, C.; Ramme, I. Online marketing of green electricity in Germany-A content analysis of providers' websites. Energy Policy 2014, 66, 257-266. [CrossRef]

30. Rommel, J.; Sagebiel, J.; Müller, J.R. Quality uncertainty and the market for renewable energy: Evidence from German consumers. Renew. Energy 2016, 94, 106-113. [CrossRef]

31. Sagebiel, J.; Müller, J.R.; Rommel, J. Are consumers willing to pay more for electricity from cooperatives? Results from an online Choice Experiment in Germany. Energy Res. Soc. Sci. 2014, 2, 90-101. [CrossRef]

32. Osterwalder, A.; Pigneur, Y.; Tucci, C.L. Clarifying Business Models: Origins, Present, and Future of the Concept. CAIS 2005, 16. [CrossRef]

33. Teece, D.J. Business Models, Business Strategy and Innovation. Long Range Plan. 2010, 43, 172-194. [CrossRef]

34. Zott, C.; Amit, R.; Massa, L. The Business Model: Recent Developments and Future Research. J. Manag. 2011, 37, 1019-1042. [CrossRef]

35. Boons, F.; Montalvo, C.; Quist, J.; Wagner, M. Sustainable innovation, business models and economic performance: An overview. J. Clean. Prod. 2013, 45, 1-8. [CrossRef]

36. Boons, F.; Lüdeke-Freund, F. Business models for sustainable innovation: State-of-the-art and steps towards a research agenda. J. Clean. Prod. 2013, 45, 9-19. [CrossRef]

37. Burger, S.P.; Luke, M. Business models for distributed energy resources: A review and empirical analysis. Energy Policy 2017, 109, 230-248. [CrossRef]

38. Bocken, N.; Short, S.W.; Rana, P.; Evans, S. A literature and practice review to develop sustainable business model archetypes. J. Clean. Prod. 2014, 65, 42-56. [CrossRef]

39. Aslani, A.; Mohaghar, A. Business structure in renewable energy industry: Key areas. Renew. Sustain. Energy Rev. 2013, 27, 569-575. [CrossRef]

40. Engelken, M.; Römer, B.; Drescher, M.; Welpe, I.M.; Picot, A. Comparing drivers, barriers, and opportunities of business models for renewable energies: A review. Renew. Sustain. Energy Rev. 2016, 60, 795-809. [CrossRef]

41. Klagge, B.; Schmole, H.; Seidl, I.; Schön, S. Zukunft der deutschen Energiegenossenschaften. Raumforsch. Raumordn. 2016, 74, 243-258. [CrossRef]

42. Richter, M. Utilities' business models for renewable energy: A review. Renew. Sustain. Energy Rev. 2012, 16, 2483-2493. [CrossRef]

43. Richter, M. Business model innovation for sustainable energy: German utilities and renewable energy. Energy Policy 2013, 62, 1226-1237. [CrossRef]

44. Strupeit, L.; Palm, A. Overcoming barriers to renewable energy diffusion: Business models for customer-sited solar photovoltaics in Japan, Germany and the United States. J. Clean. Prod. 2016, 123, 124-136. [CrossRef]

45. Chesbrough, H. Business Model Innovation: Opportunities and Barriers. Long Range Plan. 2010, 43, 354-363. [CrossRef]

46. Hellström, M.; Tsvetkova, A.; Gustafsson, M.; Wikström, K. Collaboration mechanisms for business models in distributed energy ecosystems. J. Clean. Prod. 2015, 102, 226-236. [CrossRef]

47. Zott, C.; Amit, R. Business Model Design: An Activity System Perspective. Long Range Plan. 2010, 43, 216-226. [CrossRef]

48. Zott, C.; Amit, R. Business Model Design and the Performance of Entrepreneurial Firms. Organ. Sci. 2007, 18, 181-199. [CrossRef]

49. Lusch, R.F.; Vargo, S.L. Service-dominant logic: Reactions, reflections and refinements. Mark. Theory 2006, 6, 281-288. [CrossRef]

50. Dilger, M.G.; Konter, M.; Voigt, K.-I. Introducing a co-operative-specific business model: The poles of profit and community and their impact on organizational models of energy co-operatives. J. Co-Oper. Organ. Manag. 2017, 5, 28-38. [CrossRef]

51. Bolinger, M. Community Wind Power Ownership Schemes in Europe and Their Relevance to the United States. Funded by the DoE under Contract No. DE-ACO3-76SF00098. 2001. Available online: https:/ / www.osti.gov/servlets/purl/827946 (accessed on 4 November 2020).

52. Creamer, E.; Aiken, G.T.; van Veelen, B.; Walker, G.; Devine-Wright, P. Community renewable energy: What does it do?: Walker and Devine-Wright (2008) ten years on. Energy Res. Soc. Sci. 2019, 57, 101223. [CrossRef]

53. Hicks, J.; Ison, N. Community-owned renewable energy (CRE): Opportunities for rural Australia. Rural Soc. $2011,20,244-255$. [CrossRef]

54. Hoicka, C.E.; MacArthur, J.L. From tip to toes: Mapping community energy models in Canada and New Zealand. Energy Policy 2018, 121, 162-174. [CrossRef]

55. Holstenkamp, L. What do we know about cooperative sustainable electrification in the global South?: A synthesis of the literature and refined social-ecological systems framework. Renew. Sustain. Energy Rev. 2019, 109, 307-320. [CrossRef]

56. Klein, S.J.W.; Coffey, S. Building a sustainable energy future, one community at a time. Renew. Sustain. Energy Rev. 2016, 60, 867-880. [CrossRef]

57. Magnusson, D.; Palm, J. Come Together: The Development of Swedish Energy Communities. Sustainability 2019, 11, 1056. [CrossRef]

58. Oteman, M.; Wiering, M.; Helderman, J.-K. The institutional space of community initiatives for renewable energy: A comparative case study of the Netherlands, Germany and Denmark. Energy Sustain. Soc. 2014, 4, 11. [CrossRef] 
59. Toke, D. Community wind power in Europe and in the UK. Wind Eng. 2005, 29, 301-308. [CrossRef]

60. Verkade, N.; Höffken, J. Collective Energy Practices: A Practice-Based Approach to Civic Energy Communities and the Energy System. Sustainability 2019, 11, 3230. [CrossRef]

61. Wierling, A.; Schwanitz, V.; Zeiß, J.; Bout, C.; Candelise, C.; Gilcrease, W.; Gregg, J. Statistical Evidence on the Role of Energy Cooperatives for the Energy Transition in European Countries. Sustainability 2018, 10, 3339. [CrossRef]

62. Mautz, R.; Byzio, A.; Rosenbaum, W. Auf dem Weg zur Energiewende. Die Entwicklung der Stromproduktion aus Erneuerbaren Energien in Deutschland; Eine Studie aus dem Soziologischen Forschungsinstitut Göttingen (SOFI); Universitätsverlag Göttingen: Göttingen, Germany, 2008; ISBN 9783938616987.

63. Gorroño-Albizu, L.; Sperling, K.; Djørup, S. The past, present and uncertain future of community energy in Denmark: Critically reviewing and conceptualising citizen ownership. Energy Res. Soc. Sci. 2019, 57, 101231. [CrossRef]

64. Fischer, B.; Wetzel, H. Entwicklungsdynamik und Strukturelle Merkmale von Energiegenossenschaften in Deutschland in den Jahren von 2009 bis 2015. klimaGEN-Working Paper. 2018. Available online: https://klimagen.de/fileadmin/user_upload/ KlimaGEN_Arbeitspapier_1_web.pdf (accessed on 4 November 2020).

65. Roby, H.; Dibb, S. Future pathways to mainstreaming community energy. Energy Policy 2019, 135, 111020. [CrossRef]

66. Bauwens, T.; Gotchev, B.; Holstenkamp, L. What drives the development of community energy in Europe?: The case of wind power cooperatives. Energy Res. Soc. Sci. 2016, 13, 136-147. [CrossRef]

67. Randles, S.; Laasch, O. Theorising the normative business model. Organ. Environ. 2016, 29, 53-73. [CrossRef]

68. Yunus, M.; Moingeon, B.; Lehmann-Ortega, L. Building social business models: Lessons from the Grameen experience. Long Range Plan. 2010, 43, 308-325. [CrossRef]

69. Kahla, F. Implementation of a balanced scorecard for hybrid business models: An application for citizen renewable energy companies in Germany. Int. J. Energy Sect. Manag. 2017, 11, 426-443. [CrossRef]

70. Bauwens, T.; Huybrechts, B.; Dufays, F. Understanding the diverse scaling strategies of social enterprises as hybrid organizations: The case of renewable energy cooperatives. Organ. Environ. 2020, 33, 195-219. [CrossRef]

71. Becker, S.; Kunze, C.; Vancea, M. Community energy and social entrepreneurship: Addressing purpose, organisation and embeddedness of renewable energy projects. J. Clean. Prod. 2017, 147, 25-36. [CrossRef]

72. Bauwens, T. Explaining the diversity of motivations behind community renewable energy. Energy Policy 2016, 93, 278-290. [CrossRef]

73. Rogers, J.C.; Simmons, E.A.; Convery, I.; Weatherall, A. Public perceptions of opportunities for community-based renewable energy projects. Energy Policy 2008, 36, 4217-4226. [CrossRef]

74. Bird, C.; Barnes, J. Scaling up community activism: The role of intermediaries in collective approaches to community energy. PPP 2014, 8, 208-221. [CrossRef]

75. Brown, D. Business models for residential retrofit in the UK: A critical assessment of five key archetypes. Energy Effic. 2018, 11, 1497-1517. [CrossRef]

76. Hargreaves, T.; Hielscher, S.; Seyfang, G.; Smith, A. Grassroots innovations in community energy: The role of intermediaries in niche development. Glob. Environ. Chang. 2013, 23, 868-880. [CrossRef]

77. Nolden, C. Governing community energy: Feed-in tariffs and the development of community wind energy schemes in the United Kingdom and Germany. Energy Policy 2013, 63, 543-552. [CrossRef]

78. Creamer, E.; Eadson, W.; van Veelen, B.; Pinker, A.; Tingey, M.; Braunholtz-Speight, T.; Markantoni, M.; Foden, M.; Lacey-Barnacle, M. Community energy: Entanglements of community, state, and private sector. Geogr. Compass 2018, 12, e12378. [CrossRef]

79. Schmid, B.; Meister, T.; Klagge, B.; Seidl, I. Energy cooperatives and municipalities in local energy governance arrangements in Switzerland and Germany. J. Environ. Dev. 2020, 29, 123-146. [CrossRef]

80. Meister, T. Kooperationsstrukturen von Energiegenossenschaften in Deutschland: Ergebnisse einer Befragung. Z. Gesamte Genoss. 2020, 70, 8-30. [CrossRef]

81. Meister, T.; Schmid, B.; Seidl, I.; Klagge, B. How municipalities support energy cooperatives: Survey results from Germany and Switzerland. Energy Sustain. Soc. 2020, 10, 18. [CrossRef]

82. Goedkoop, F.; Devine-Wright, P. Partnership or placation?: The role of trust and justice in the shared ownership of renewable energy projects. Energy Res. Soc. Sci. 2016, 17, 135-146. [CrossRef]

83. Borgatti, S.P.; Foster, P.C. The network paradigm in organizational research: A review and typology. J. Manag. 2003, 29, 991-1013.

84. Brass, D.J.; Galaskiewicz, J.; Greve, H.R.; Tsai, W. Taking stock of networks and organizations: A multilevel perspective. Acad. Manag. J. 2004, 47, 795-817.

85. Gulati, R.; Nohria, N.; Zaheer, A. Strategic networks. Strateg. Manag. J. 2000, 21, 203-215. [CrossRef]

86. Jarillo, J.C. On strategic networks. Strateg. Manag. J. 1988, 9, 31-41. [CrossRef]

87. Turnbull, P.; Ford, D.; Cunningham, M. Interaction, relationships and networks in business markets: An evolving perspective. J. Bus. Ind. Mark. 1996, 11, 44-62. [CrossRef]

88. Chen, H.; Chen, T.-J. Governance structures in strategic alliances: Transaction cost versus resource-based perspective. J. World Bus. 2003, 38, 1-14. [CrossRef]

89. Mellewigt, T.; Madhok, A.; Weibel, A. Trust and formal contracts in interorganizational relationships-Substitutes and complements. Manag. Decis. Econ. 2007, 28, 833-847. [CrossRef]

90. Das, T.K.; Teng, B.-S. A resource-based theory of strategic alliances. J. Manag. 2000, 26, 31-61. [CrossRef] 
91. Mayer, K.J.; Salomon, R.M. Capabilities, contractual hazards, and governance: Integrating resource-based and transaction cost perspectives. Acad. Manag. J. 2006, 49, 942-959. [CrossRef]

92. Dacin, M.T.; Oliver, C.; Roy, J.-P. The legitimacy of strategic alliances: An institutional perspective. Strateg. Manag. J. 2007, 28, 169-187. [CrossRef]

93. Upward, A.; Jones, P.H. An Ontology for Strongly Sustainable Business Models: Defining an Enterprise Framework Compatible with Natural and Social Science. Organ. Environ. 2015, 29. [CrossRef]

94. Dixit, A.K. Economic Governance. In The New Palgrave Dictionary of Economics, Living ed.; Palgrave Macmillan UK: London, UK, 2019; pp. 1-11. ISBN 978-1-349-95121-5.

95. Yin, R.K. Case Study Research and Applications. Design and Methods, 6th ed.; SAGE: Los Angeles, CA, USA; London, UK; New Dehli, India; Singapore; Washington, DC, USA; Melbourne, Australia, 2018; ISBN 1506336167.

96. Baskerville, R.; Pries-Heje, J. Explanatory Design Theory. Bus. Inf. Syst. Eng. 2010, 2, 271-282. [CrossRef]

97. Mayring, P. Qualitative Inhaltsanalyse. Grundlagen und Techniken; 12 überarb. Aufl.; Beltz: Weinheim, Germany, 2015; ISBN 3407293933.

98. Fisher-Buttinger, C.; Vallaster, C. Connective Branding. Building Brand Equity in a Demanding World; John Wiley \& Sons: London, UK, 2008; ISBN 1119208394.

99. Vallaster, C.; Kraus, S. Entrepreneurial branding: Growth and its implications for brand management. Int. J. Entrep. Small Bus. 2011, 14, 369-390. [CrossRef]

100. Eggers, F.; O’Dwyer, M.; Kraus, S.; Vallaster, C.; Güldenberg, S. The impact of brand authenticity on brand trust and SME growth: A CEO perspective. J. World Bus. 2013, 48, 340-348. [CrossRef]

101. Gelazanskas, L.; Gamage, K.A. Demand side management in smart grid: A review and proposals for future direction. Sustain. Cities Soc. 2014, 11, 22-30. [CrossRef]

102. Friis, F.; Haunstrup Christensen, T. The challenge of time shifting energy demand practices: Insights from Denmark. Energy Res. Soc. Sci. 2016, 19, 124-133. [CrossRef]

103. Viardot, E. The role of cooperatives in overcoming the barriers to adoption of renewable energy. Energy Policy 2013, 63, 756-764. [CrossRef]

104. Wüstenhagen, R.; Wolsink, M.; Bürer, M.J. Social acceptance of renewable energy innovation: An introduction to the concept. Energy Policy 2007, 35, 2683-2691. [CrossRef]

105. van der Horst, D. NIMBY or not? Exploring the relevance of location and the politics of voiced opinions in renewable energy siting controversies. Energy Policy 2007, 35, 2705-2714. [CrossRef]

106. Friege, C.; Herbes, C. Konzeptionelle Überlegungen zur Vermarktung von Erneuerbaren Energien. In Marketing Erneuerbarer Energien: Grundlagen, Geschäftsmodelle, Fallbeispiele; Herbes, C., Friege, C., Eds.; Springer Gabler: Wiesbaden, Germany, 2015; ISBN 978-3-658-04967-6. 